2012

\title{
Preventing Mass Atrocity Crimes: The Responsibility to Protect and the Syria Crisis
}

Paul R. Williams

Jonathan Worboys

J. Trevor Ulbrick

Follow this and additional works at: https://scholarlycommons.law.case.edu/jil

Part of the International Law Commons

\section{Recommended Citation}

Paul R. Williams, Jonathan Worboys, and J. Trevor Ulbrick, Preventing Mass Atrocity Crimes: The Responsibility to Protect and the Syria Crisis, 45 Case W. Res. J. Int'1 L. 473 (2012)

Available at: https://scholarlycommons.law.case.edu/jil/vol45/iss1/13 


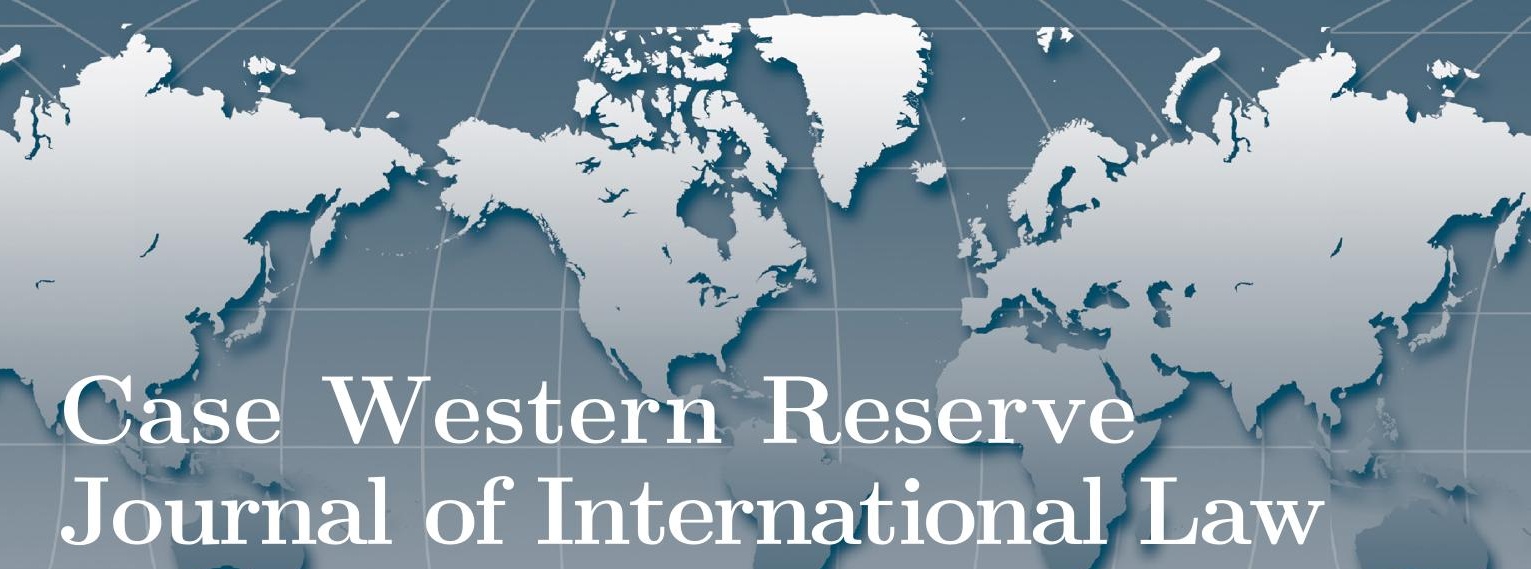

Preventing Mass Atrocity Crimes: The Responsibility to Protect and The Syria Crisis

Paul R. Williams, J. Trevor Ulbrick $\&$ Jonathan Worboys 


\title{
Preventing Mass Atrocity \\ Crimes: The Responsibility to \\ Protect AND The Syria Crisis
}

\author{
Paul R. Williams, ${ }^{*}$ J. Trevor Ulbrick, ${ }^{\dagger}$ G Jonathan Worboys ${ }^{\ddagger}$
}

\section{CONTENTS}

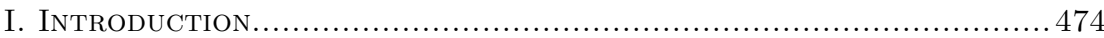

II. Background to the Responsibility to Protect Doctrine ........4 477

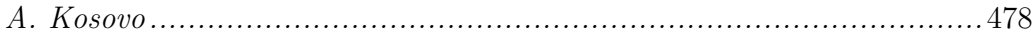

B. The Right of Humanitarian Intervention......................................... 479

III. Emergence of the Responsibility to Protect Doctrine..........4 481

A. Content of the ICISS Report.......................................... 481

B. UN Evolution of RQP .............................................. 483

IV. R2P's Third Pillar And the Use of Force ........................... 486

A. Pillar Three of the Responsibility to Protect ..............................486

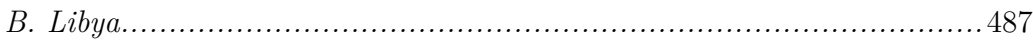

V. R2P AND the Syria CRISIS .......................................... 488

A. Preventing and Halting Atrocity Crimes When the Security Council Fails to Act ........................................................... 489

B. Pillar Three of the Responsibility to Protect When the Security Council Fails to Act .................................................. 491

1. A prima facie case must be established ........................................491

2. Peaceful options must be exhausted ..................................................495

3. The Security Council must be unable to act ................................497

4. Military force must be limited to low-intensity options designed to protect populations.

5. The use of low-intensity military force must be authorized by a legitimate authority

* Dr. Paul R. Williams is the Rebecca I. Grazier Professor of Law and International Relations at American University. He is also the cofounder and President of the Public International Law \& Policy Group. Ph.D Cambridge University, J.D. Stanford Law School, A.B. UC Davis. The Public International Law \& Policy Group provides pro bono legal assistance to the Syrian opposition. The authors would like to thank Caitlin Behles for her useful comments on earlier drafts of this article.

$\dagger \quad$ J. Trevor Ulbrick is an attorney and Law Fellow with the Public International Law \& Policy Group. J.D. cum laude Northwestern University School of Law, M.A. University of Chicago (Distinction), University College London, B.A. Washington \& Lee University.

$\ddagger$ Jonathan Worboys is a barrister and Law Fellow with the Public International Law \& Policy Group. BCL University of Oxford, LL.B (First Class Honours) King's College London. 
6. The intervention must come at the request of credible opposition groups .................................................................. 501

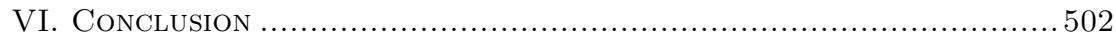

\section{INTRODUCTION}

The Responsibility to Protect (R2P) is a complicated and "emerging norm"1 of international law that seeks to provide a means for the international community to prevent mass atrocity crimes occurring within the boundaries of a sovereign state. ${ }^{2}$ Since its emergence in 2001, in the wake of humanitarian tragedies in Bosnia, Rwanda, Kosovo, and Darfur, R2P has been hailed as a way of resolving what one commentator called the "problem from hell." ${ }_{3}$ Under R2P, however, the use of force is reserved for actions within the UN Charter's Chapter VII framework. As the Syria crisis has demonstrated, this position continues to hinder efforts by the international community to protect populations from mass atrocity crimes.

This article argues that when peaceful measures have been exhausted and the Security Council is deadlocked, R2P's third pillar should allow the use of only those low-intensity military options, such as no-fly zones and humanitarian safe havens, that are focused on protecting populations. This approach would advance R2P's development by establishing specific criteria that allow for the limited use of force when the Security Council fails to act. In doing so, R2P will be able to fulfill its primary purpose of preventing mass atrocities within a sovereign state, thus preventing humanitarian tragedies similar to those witnessed in Bosnia, Rwanda, Darfur, and now Syria.

At the time of writing, attacks by Syrian government forces and militias have killed upward of 75,000 civilians, and approximately

1. The Secretary-General's High-level Panel on Threats, Challenges, and Change, A More Secure World: Our Shared Responsibility, ๆ 203, U.N. Doc. A/59/565 (Dec. 2004) (describing the Responsibility to Protect as an "emerging norm") [hereinafter A More Secure World]. See also S.C. Res. 1674, U.N. Doc. S/RES/1674 (Apr. 28, 2006) ("Reaffirm[ing] the provisions of paragraphs 138 and 139 of the 2005 World Summit Outcome Document regarding the responsibility to protect populations from genocide, war crimes, ethnic cleansing and crimes against humanity[.]"). Notably, this resolution was ultimately supported by Russia and China, each of whom had initially expressed reservations about the implications of R2P for state sovereignty.

2. The international community's ultimate response to the Syria crisis will contribute to the shape of R2P.

3. Samantha Power, A Problem from Hell: America and the Age of GENOCIDE (2003). 
$1,000,000$ refugees have fled into neighboring states. ${ }^{4}$ The international community has tried to resolve the Syria crisis through diplomatic overtures and sanctions, but its attempts have been unsuccessful. Although the UN Human Rights Council has concluded that Syria's humanitarian crisis is being driven by a "state policy" of deliberate attacks against civilians ${ }^{5}$ military intervention by the Security Council has not been forthcoming.

Russia and China oppose any coercive measures against Syria, with Russia contending that the international community should "strictly adhere to the norms of international law. . . ." While Russia's opposition is likely grounded in their strategic self-interest, ${ }^{7}$ some states remain concerned that humanitarian action "could be abused by powerful states as justification for interventions that serve their political interests." 8 Given the Security Council's ineffectiveness

4. William Hague, Foreign Secretary, Statement to Parliament on Syria (Mar. 6, 2013), available at https://www.gov.uk/government/speeches/ foreign-secretary-statement-to-parliament-on-syria. See also Syria Regional Refugee Response, UN High Comm'n on Refugees, http://data.unhcr.org/syrianrefugees/regional.php (last visited Mar. 26, 2013).

5. See Independent International Commission of Inquiry, Report of the Independent International Commission of Inquiry on the Syrian Arab Republic, ๆ 50, 57, U.N. Doc. A/HCR/21/50 (Aug. 16, 2012) [hereinafter Report on Syrian Arab Republic], available at http://www. ohchr.org/Documents/HRBodies/HRCouncil/RegularSession/Session21/ A-HRC-21-50_en.pdf.

6. Syria Crisis: Russia Warns Obama Against 'Violation' of International Law, NBC, Aug. 22, 2012, http://worldnews.nbcnews.com/_news/2012 /08/22/13409128-syria-crisis-russia-warns-obama-against-violation-ofinternational-law?lite.

7. See, e.g., Christopher Harmer, Russian Naval Base Tartus, Inst. FoR THE STUDY OF WAR (July 31, 2012), http://www.understandingwar. org/backgrounder/russian-naval-base-tartus (explaining the strategic significance of Russia's naval base at Tartus).

8. Christoph Mikulaschek, The United Nations Security Council and the Responsibility to Protect: Policy, Process, and Practice. Report from the 39th International Peace Institute Vienna Seminar on Peacemaking and Peacekeeping, in THE UN SECuRITY COUNCIL AND THE Responsibility to Protect 20, 24 (2010), available at http://www.ipac ademy.org/media/pdf/publications/favorita_paper_2010.pdf. For a Chinese perspective on R2P in Syria, see Qu Xing, The UN Charter, the Responsibility to Protect, and the Syria Issue, CHInA Inst. OF INT'L STUD., (Apr. 16, 2012), http://www.ciis.org.cn/english/2012-04/16/con tent_4943041.htm. In response to the Syria crisis, other states, led by Brazil, have proposed an alternative doctrine called the Responsibility While Protecting (RWP), which holds that refining the criteria for the legitimate use of coercive force will encourage the Security Council to act decisively to prevent mass atrocity crimes. See U.N. General Assembly, Letter dated Nov. 9, 2011from the Permanent Representative 
in the Syria crisis, some commentators have argued that R2P advocates must either "mobilize a coalition of the willing" to intervene in Syria or "let R2P . . . rest in peace." ${ }^{\text {O }}$ Others have called for reform of the Security Council where mass atrocity crimes are at issue. ${ }^{10}$

The Syria crisis highlights the current limitations of the R2P doctrine. Despite R2P's important contributions to the protection of populations over the past decade, the Security Council's veto system can still create situations where states can commit mass atrocity crimes against their citizens. At present, R2P lacks a framework for the limited use of force when the Security Council fails to act. In its present formulation, therefore, $\mathrm{R} 2 \mathrm{P}$ is missing a crucial component.

This article first provides a background to R2P, discussing the debate surrounding the legality of "the right of humanitarian intervention." It then discusses the emergence of R2P, providing an overview of R2P's third pillar, which authorizes the use of force. This article then continues to argue that R2P's third pillar should provide for the limited use of force without Security Council authorization.

Since any use of force outside the Security Council would be at the limits of international law, this article sets forth specific criteria that must be satisfied before the international community could act under R2P's third pillar: (1) a prima facie case must be established; (2) peaceful options must be exhausted; (3) the Security Council must be unable to act; (4) any military force used must be limited to lowintensity options designed to protect populations; (5) the use of lowintensity military force must be authorized by a legitimate authority; and (6) the intervention must come at the request of credible opposition groups. Although the use of force without Security Council authorization is a complicated and delicate question, this article argues that these criteria are the most appropriate way to develop $\mathrm{R} 2 \mathrm{P}$ moving forward.

of Brazil to the United Nations Maria L. R. Viotti addressed to the Secretary-General, U.N. Doc. A/66/551-S/2011/701 (Nov. 11, 2011).

9. Stewart M. Patrick, RIP for R2P? Syria and the Dilemmas of Humanitarian Intervention, COUNCIL ON FOREIGN RELATIONS (June 12, 2012), http://blogs.cfr.org/patrick/2012/06/12/rip-for-r2p-syria-and-thedilemmas-of-humanitarian-intervention/.

10. See Ben Sharples, New Zealand Wants Security Council Veto Change Amid Syria Crisis, Bloomberg Businessweek, Sept. 30, 2012, http:// www.businessweek.com/news/2012-09-29/new-zealand-wants-securitycouncil-veto-change-amid-syria-crisis. 


\section{Background to the Responsibility to Protect DOCTRINE}

R2P was born out of the humanitarian tragedies of the 1990s and the international community's disagreements as to whether international law recognized a "right of humanitarian intervention," in effect a right to use force for the purposes of preventing mass human rights abuses. ${ }^{11}$ Although the protection and promotion of human rights featured as one of the United Nations' principal purposes, ${ }^{12}$ the UN Charter both generally prohibited the use of force $^{13}$ and guaranteed a state's right to be free from intervention, except for measures authorized by the Security Council under its Chapter VII powers or through state actions taken in self-defense. ${ }^{14}$

The tension created by the competing concerns of human rights and national sovereignty led to uncertainty about how far the international community could go to intervene in a sovereign state in the face of major human rights violations. Questions arose regarding whether the Security Council had the authority to intervene in matters that were wholly within the borders of a state, and whether, barring Security Council action or a valid claim of self-defense, other states could lawfully take action to stop mass human rights violations. ${ }^{15}$ As a result, the international community's ability to

11. See International Commission on Intervention and State Sovereignty, The Responsibility to ProteCt: Report of the International Commission on Intervention and State Sovereignty VII (2001) [hereinafter ICISS REPORT], available at http://responsib ilitytoprotect.org/ICISS\%20Report.pdf. Humanitarian intervention is defined as "the question of when, if ever, it is appropriate for states to take coercive - and in particular military - action, against another state for the purposes of protecting people at risk in that other state."

12. See U.N. Charter art. 1, para. 3 ("To achieve international cooperation in solving international problems of an economic, social, cultural, or humanitarian character, and in promoting and encouraging respect for human rights and for fundamental freedoms for all without discrimination as to race, sex, language, or religion.").

13. See id. art. 2, para. 4 (prohibiting the use of force against sovereign states).

14. See id. art. 2 para. 7 ("Nothing contained in the present Charter shall authorize the United Nations to intervene in matters which are essentially within the domestic jurisdiction of any state or shall require the Members to submit such matters to settlement under the present Charter; but this principle shall not prejudice the application of enforcement measures under Chapter VII."); $i d$. art. 51 ("Nothing in the present Charter shall impair the inherent right of individual or collective self-defence. . . .").

15. Christopher C. Joyner, "The Responsibility to Protect": Humanitarian Concern and the Lawfulness of Armed Intervention, 47 VA. J. INT'L L. 693, 702-03 (2007). 
prevent mass atrocities was handicapped. ${ }^{16}$ This situation not only led to the death of nearly one million in Bosnia and Rwanda, ${ }^{17}$ but also NATO's controversial (but legitimate) ${ }^{18}$ military intervention to prevent mass human rights abuses in Kosovo.

\section{A. Kosovo}

In 1998, Yugoslav President Slobodan Milošević commenced attacks on ethnic Albanian civilians as part of a campaign against the Kosovo Liberation Army (KLA). ${ }^{19}$ At first, the Security Council responded to the human rights violations with Resolution 1199. ${ }^{20} \mathrm{In}$ this resolution, the Security Council labeled the situation in Kosovo a threat to "peace and security." 21 The Security Council also adopted provisional measures that demanded the parties cease hostilities and take steps toward a conciliatory dialogue. ${ }^{22}$ In the months that followed, as President Milošević continued to order attacks on civilians and civilian-populated areas, it became apparent that stronger measures would be required to end the mass human rights abuses. ${ }^{23}$ The Security Council, however, failed to authorize further coercive measures to prevent mass atrocities.

Facing a deadlocked Security in March 1999, NATO conducted Operation Allied Force, a seventy-seven day campaign of air strikes that ended the conflict in Kosovo. ${ }^{24}$ The campaign was launched following numerous failed diplomatic efforts by NATO, the UN, and the Organization for Security and Cooperation in Europe (OSCE). The mission's aim was to disable Serbia's military capacity to attack Kosovar Albanians. ${ }^{25}$ It included contributions from all nineteen NATO member states, and ended with the agreement of Serbia to

16. See id. at 694, 698-700, 704 .

17. See id.

18. See generally IndePEndent International Commission on Kosovo, Kosovo RePORT (2000) [hereinafter Kosovo REPORT], available at http://reliefweb.int/sites/reliefweb.int/files/resources/F62789D9FCC56 FB3C1256C1700303E3B-thekosovoreport.htm.

19. Id.

20. S.C. Res. 1199, U.N. Doc. S/RES/1199 (Sep. 23, 1998).

21. See id. pmbl.

22. See generally id.

23. See Kosovo RePORT, supra note 18.

24. See NATO's Role in Relation to the Conflict in Kosovo, NATO (July 15, 1999), http://nato.int/kosovo/history.htm.

25. U.S. Department of Defense, Operation Allied Force (June 21, 1999), available at http://www.defense.gov/specials/kosovo/. 
cease hostile actions and to withdraw its military forces and political apparatus from Kosovo. ${ }^{26}$

\section{B. The Right of Humanitarian Intervention}

At the Security Council in March 1999, the United Kingdom justified its actions in Kosovo on the doctrine of "humanitarian intervention." ${ }^{27}$ The United Kingdom argued that an exception to the UN Charter's prohibition on the use of force had emerged that allowed states to use force, only for the purposes of preventing mass human rights abuses, when: (1) there is convincing evidence of extreme humanitarian distress on a large scale that requires immediate urgent relief; (2) it is objectively clear that there is no practicable alternative to the use of force if lives are to be saved; and (3) the proposed use of force is necessary and proportionate to the aim of humanitarian intervention. ${ }^{28}$ Importantly, the United Kingdom asserted that the right of humanitarian intervention legally justified military intervention without explicit Security Council authorization..$^{29}$

NATO's actions in Kosovo, though ultimately regarded as legitimate ${ }^{30}$ were at the time highly controversial. Those opposing the doctrine of humanitarian intervention, as proposed by the United Kingdom, often argued it could not be considered customary international law as it lacked sufficient basis in state practice and opinio juris. ${ }^{31}$ These individuals noted that claims of humanitarian intervention were made on a selective basis and that many instances of state practice relied upon to support such a right were justified on the basis of self-defense and not a right of humanitarian intervention. ${ }^{32}$ Detractors also argued that humanitarian intervention without explicit Security Council authorization was an illegitimate

26. See id.; Rand Corporation, Operation Allied Force: Lessons for Future Coalition Operations (Research Brief 72-AF, 2001), available at http://www.rand .org/pubs/research_briefs/RB72/index1.html.

27. Sir Christopher Greenwood, Humanitarian Intervention: The Case of Kosovo, 10 Finnish Y.B. INT'L L. 141, 157 (2002).

28. For a detailed discussion of the United Kingdom's legal argument, see $i d$. at $157-60$.

29. See $i d$. at 157.

30. See Kosovo Report, supra note 18 ("The Commission concludes that the NATO military intervention was illegal but legitimate.").

31. J. L. Holzgrefe, The Humanitarian Intervention Debate, in Humanitarian Intervention: Ethical, Legal And Political Dilemmas 46 (J.L. Holzgrefe \& Robert O. Keohane eds., 2003) ("In support of this contention, they point to the highly selective exercise of the right of unauthorized humanitarian intervention in recent history.").

32. See id. at 46-47; Malcolm Evans, International Law 622 (2010). 
infringement on state sovereignty that violated the UN Charter's prohibition on the use of force. ${ }^{33}$

Despite these arguments, the concept of a right of humanitarian intervention gradually gained traction in the international community. Some influential academics, notably Sir Christopher Greenwood, argued "modern customary international law recognizes a right of military intervention on humanitarian grounds by States, or an organization like NATO." ${ }^{34}$ In support of his conclusions, Sir Christopher traced state practice back as far India's intervention to end repression in Bangladesh. ${ }^{35}$ Others traced a customary international law right of humanitarian intervention back to Tanzania's intervention to overthrow Idi Amin in Uganda and Vietnam's use of force to end the rule of Pol Pot in Cambodia. ${ }^{36}$ Supporters also contended that the historically selective use of humanitarian intervention did not disprove its existence, since humanitarian intervention was conceived as a right to intervene and not an obligation. ${ }^{37}$ Furthermore, even those instances of state practice that relied on self-defense as a justification for their actions, were, in reality, a form of humanitarian intervention. ${ }^{38}$ In Uganda, for instance, Tanzania did not merely repel attacks, but overthrew a repressive regime. ${ }^{39}$

The arguments for and against the right of humanitarian intervention demonstrate the controversial nature of the concept within international law. Humanitarian intervention evolved from a once widely disregarded policy into a compelling justification for the use of force to prevent mass human rights violations. While humanitarian intervention's status as a norm of customary international law remains contentious, state practice and opinio juris suggest that a strong argument can be made for the right's legality.

33. Ian Brownlie, Humanitarian Intervention, in LAW AND CIVIL WAR IN Modern World 217-28 (J.N. Moore ed., 1974).

34. Greenwood, supra note 27 , at 170.

35. Id. at 163 .

36. See EvAns, supra note 32 , at 621 .

37. See Holzgrefe, supra note 31 , at 47 (arguing that the very nature of a right implies an element of selectivity concerning when it is applied, which is different from the obligation to act).

38. See Greenwood, supra note 27, at 163.

39. Id. 


\section{Emergence of the Responsibility to Protect DOCTRINE}

In the aftermath of Rwanda, Bosnia, and Kosovo ${ }^{40}$ it was plain that the international community lacked an effective framework to prevent or stop mass atrocities. Consequently, in 2000, UN SecretaryGeneral Kofi Annan asked: "[I]f humanitarian intervention is, indeed, an unacceptable assault on sovereignty, how should we respond to a Rwanda, to a Srebrenica - to gross and systematic violations of human rights that offend every precept of our common humanity?" ${ }_{41}$

In 2001, the International Commission on Intervention and State Sovereignty (ICISS), ${ }^{42}$ an independent, Canadian-sponsored commission, responded by publishing a report "about the . . 'right of humanitarian intervention." "43 Upon considering international law's growing emphasis on protecting populations, the ICISS report concluded that the concept of state sovereignty, and our understanding of it, must entail a state's responsibility to protect its own citizens. ${ }^{44}$ ICISS coined this proposal the responsibility to protect, or $\mathrm{R} 2 \mathrm{P}$.

\section{A. Content of the ICISS Report}

Following more than a year of research, interviews, and investigation, ${ }^{45}$ ICISS found that since the Peace of Westphalia, ${ }^{46}$ international norms had shifted such that state sovereignty was no longer inviolate. ${ }^{47}$ In the twenty-first century, ICISS found sovereignty entailed responsibility: in particular, the responsibility to protect populations from mass human rights violations. ${ }^{48}$

40. See Kosovo Report, supra note 18.

41. ICISS REPORT, supra note 11, at VII.

42. See generally id.

43. Id. at VII.

44. Id. at XI.

45. See Lloyd Axowrthy, RtoP and the Evolution of State Sovereignty, in The Responsibility to Protect 3, 11 (Jared Genser and Irwin Cotler eds., 2012).

46. The Peace of Westphalia was a treaty signed by the warring states of Europe in 1648. It is regarded as providing for the modern foundations of the system of international relations. See Treaty of Westphalia, THE Avalon ProJect, available at http://avalon.law.yale.edu/17thcentury /westphal.asp.

47. ICISS REPORT, supra note 11, at XI.

48. Id. at $32-33$. In addition to atrocity crimes, ICISS also provided that:

[Military] intervention for human protection purposes [is justified] . . . to halt or avert . . . situations of state collapse and 
As part of the responsibility to protect, ICISS proposed that states had three separate, but interlinked duties. First, individual states were primarily responsible for protecting their populations. ${ }^{49}$ ICISS categorized this aspect of the R2P as a state's "responsibility to prevent," outlining a state's obligation to eliminate the root causes of mass atrocities. ${ }^{50}$

Second, ICISS found that where a state fails to protect its population-or is the driving force behind mass atrocities - the responsibility to protect shifts to the international community. ${ }^{51}$ ICISS categorized this aspect of R2P as the "responsibility to react," stating that in responding to mass atrocities, the international community must first exhaust peaceful options, following which force can be used in extreme circumstances. ${ }^{52}$

Third, ICISS found that after the use of force to prevent mass atrocities, states should help post-conflict states rebuild. In doing so, ICISS held that states should provide full assistance to support recovery efforts, reconstruction, and reconciliation. ${ }^{53}$ ICISS framed this aspect of $\mathrm{R} 2 \mathrm{P}$ as the "responsibility to rebuild," making clear that when acting pursuant to its responsibility to rebuild, the international community should pay particular attention to addressing the causes of harm that an intervention was designed to halt or avert. ${ }^{54}$

In reaching its conclusions, the ICISS report addressed two of international law's most controversial questions: when could states use force to protect populations and which authorities would be competent to authorize it? ICISS first found that the international community could use force to prevent atrocities when attempts to resolve crises by peaceful options had been exhausted and the

the resultant exposure of the population to mass starvation and/or civil war; and overwhelming natural or environmental catastrophes, where the state concerned is either unwilling or unable to cope, or call for assistance, and significant loss of life is occurring or threatened.

Id. at $32-36$.

49. Id. at XI.

50. Id.

51. Id. at 29 .

52. ICISS discussed the meaning of "extreme" stating that the use of force should be confined to "cases of violence which so genuinely "shock the conscience of mankind' or which present clear and present danger to international security, that they require coercive military intervention." Id. at 31 .

53. Id. at XI.

54. Id. 
circumstances faced by the international community were extreme. ${ }^{55}$ To ensure these principles were adhered to, ICISS provided a six-part test for determining whether the use of force for humanitarian purposes is warranted. ${ }^{56}$ According to ICISS, for intervention to be legitimate: (1) just cause must exist; (2) the assistance must be provided as a last resort; (3) the acting states must have rightful intentions; (4) the action must be proportional to the humanitarian crisis; (5) the action must have a reasonable chance of success; and (6) the action must be authorized by a legitimate authority. ${ }^{57}$

Regarding the competent authorities to authorize the use of force (for the purposes of protecting populations), ICISS found that the UN was the principal organization charged with the task. ${ }^{58}$ Presumably in recognition of the fact that there were likely to be future instances in which the Security Council would be deadlocked, as it had been throughout much of the 1990s, ICISS provided that when the Security Council fails to act, regional or sub-regional organizations could take collective action within their boundaries. ${ }^{59}$ Moreover, ICISS provided that a UN General Assembly Uniting for Peace Resolution could provide "a high degree of legitimacy for an intervention." 60

\section{B. UN Evolution of R2P}

Post-2001 and the ICISS report, the UN began to shape R2P. In doing so, the UN contributed to the doctrine's codification and international acceptance, but its actions also marked a subtle shift away from the ICISS formulation of R2P. In particular, the UN did not endorse or build on the ICISS Report's discussion of how the international community may respond to mass atrocities when the Security Council fails to act. ${ }^{61}$

R2P first featured on the UN agenda in 2004 when a UN Highlevel Panel on Threats, Challenges, and Change (UN High-level Panel) produced a report titled A More Secure World: Our Shared Responsibility. ${ }^{62}$ Pursuant to its mandate of generating new ideas about the policies and institutions required for the UN to be effective

55. Id. at 31 .

56. See $i d$. at $32-37$.

57. Id. at XII (applying the principles to "military interventions").

58. Id. at 53 .

59. See $i d$. at 53-54. ICISS included regional coalitions as capable of taking collective intervention within the boundaries on the basis that member states to those organizations are more familiar with local political actors and are more likely to feel the impact of the human catastrophe.

60. Id. at 53 .

61. See id. at $53-55$.

62. See A More Secure World, supra note 1. 
in the twenty-first century, ${ }^{63}$ the UN High-level Panel went on to recognize the "emerging norm that there is a collective international responsibility to protect." ${ }_{64}$

It was not until the following year at the World Summit that the UN began to shape R2P. In September 2005, 170 heads of state ${ }^{65}$ came together at the General Assembly to "take action on grave global threats that require bold global solutions." 66 This meeting produced the World Summit Outcome Document. The World Summit Document, at paragraphs 138 and 139, recognized each state's responsibility to protect populations from mass atrocity crimes: genocide, crimes against humanity, war crimes, and ethnic cleansing. ${ }^{67}$ Importantly, in paragraphs 138 and 139, states recognized that they were "prepared" 68 to take action to prevent mass atrocity crimes on a "case-by-case basis." ${ }^{99}$ In making their findings, the World Summit

\section{See id. at 1 .}

64. Id. at 66 .

65. William W. Burke-White, Adoption of the Responsibility to Protect, in The Responsibility to Protect 17, 21 (Jared Genser and Irwin Cotler eds., 2012).

66. Secretary-General Kofi Annan, Address to the 2005 World Summit (Sept. 14, 2005), available at http://www.un.org/webcast/summit2005/ statements/sgenglish3.pdf

67. For an overview of these crimes, see Tarun Chhabra and Jeremy B. Zucker, Defining the Crimes, in The ResponsibiLity to Protect 37 (Jared Genser and Irwin Cotler eds., 2012).

68. 2005 World Summit Outcome, G.A. Res. 60/1, ฯ 139, U.N. Doc. A/RES/60/1 (Oct. 24, 2005).

69. Id. ๆ ฯ $138-39$.

138. Each individual State has the responsibility to protect its populations from genocide, war crimes, ethnic cleansing and crimes against humanity. This responsibility entails the prevention of such crimes, including their incitement, through appropriate and necessary means. We accept that responsibility and will act in accordance with it. The international community should, as appropriate, encourage and help States to exercise this responsibility and support the United Nations in establishing an early warning capability.

139. The international community, through the United Nations, also has the responsibility to use appropriate diplomatic, humanitarian and other peaceful means, in accordance with Chapters VI and VIII of the Charter, to help protect populations from genocide, war crimes, ethnic cleansing and crimes against humanity. In this context, we are prepared to take collective action, in a timely and decisive manner, through the Security Council, in accordance with the Charter, including Chapter VII, on a case-by-case basis and in cooperation with relevant regional organizations as appropriate, should peaceful means be inadequate and national authorities manifestly fail to protect their populations from genocide, war crimes, ethnic cleansing and crimes against humanity. We stress the need for the General Assembly to continue consideration of 
noted that the protection of populations by the use of force was only available when authorized in accordance with the UN Charter's Chapter VII framework. ${ }^{70}$

In the wake of the UN General Assembly's acceptance of R2P, the UN Security Council "reaffirmed" the doctrine in April 2006. ${ }^{71}$ Specifically, the UN Security Council adopted paragraphs 138 and 139 of the World Summit Document in its landmark Resolution 1674 on the Protection of Civilians in Armed Conflict. ${ }^{72}$ In endorsing the World Summit's formulation of R2P, the Security Council confirmed the main protection responsibilities of $\mathrm{R} 2 \mathrm{P}$, also reaffirming the Security Council's prerogative on the use of force.

In 2009, the UN codification of R2P continued when UN Secretary-General Ban Ki-moon presented a report (SecretaryGeneral's Report) clarifying R2P so that states could implement it in a "fully faithful and consistent manner." 73 According to the SecretaryGeneral's Report, R2P should be understood as comprising three conceptual pillars. ${ }^{74}$ First, each state has the responsibility to provide security for their populations and protect them from genocide, war crimes, and crimes against humanity. ${ }^{75}$ Second, when a state lacks the capacity to protect its populations from these crimes, the international community has the responsibility to provide assistance, helping states to meet their obligations ${ }^{76}$ Third, if a state "manifestly

the responsibility to protect populations from genocide, war crimes, ethnic cleansing and crimes against humanity and its implications, bearing in mind the principles of the Charter and international law. We also intend to commit ourselves, as necessary and appropriate, to helping States build capacity to protect their populations from genocide, war crimes, ethnic cleansing and crimes against humanity and to assisting those which are under stress before crises and conflicts break out. Id.

70. Id.

71. See S.C. Res. 1674, supra note 1 ("Reaffirm[ing] the provisions of paragraphs 138 and 139 of the 2005 World Summit Outcome Document regarding the responsibility to protect populations from genocide, war crimes, ethnic cleansing and crimes against humanity.").

72. Id. Notably, the resolution was ultimately supported by Russia and China, each of whom had initially expressed reservations about the implications of Responsibility to Protect for state sovereignty.

73. U.N. Secretary-General, Implementing the Responsibility to Protect, 92 , U.N. Doc. A/63/677 (Jan. 12, 2009) [hereinafter Implementing the Responsibility to Protect]. At the subsequent General Assembly debate, over fifty states explicitly endorsed the Secretary-General's three-pillar formulation.

74. Id. ๆ 11.

75. Id. ๆ $11(\mathrm{a})$.

76. Id. ๆ $11(\mathrm{~b})$. 
fails" in its protection responsibilities, the international community should respond in a timely and decisive manner, by taking a range of peaceful, coercive, or forceful measures in accordance with the UN Charter. ${ }^{77}$ With time, the Secretary-General's "three pillar" approach has become widely accepted, having been endorsed by more than fifty states. $^{78}$

\section{R2P's Third Pillar and the Use of Force}

The use of force to protect populations is one of the most controversial issues in international law. In Bosnia and Rwanda, states and regional organizations failed to protect populations from mass atrocities. When states used force to end mass atrocities in Kosovo without Security Council authorization, however, their actions were viewed as controversial. ${ }^{79}$ With the rise of $\mathrm{R} 2 \mathrm{P}$, the international community was provided with a framework for preventing or halting the mass atrocity crimes that characterized these humanitarian tragedies.

\section{A. Pillar Three of the Responsibility to Protect}

$\mathrm{R} 2 \mathrm{P}$ is primarily concerned with the prevention of atrocity crimes through peaceful means. In doing so, R2P respects the importance international law attaches to state sovereignty, ${ }^{80}$ while also providing a framework that regularizes the use of force to protect populations. Only in rare instances will R2P permit the international community to use force. In these circumstances R2P's three-pillar framework ensures the international community will only use force when absolutely necessary.

According to the Secretary-General's Report, R2P's third pillar requires that when a state has "manifestly failed" to protect its population, the international community should respond "in a timely and decisive manner," through a "reasoned, calibrated and timely response" in accordance with the UN Charter. ${ }^{81}$ This formulation of

77. Id. \ 11(c).

78. See Global Center for the Responsibility to Protect, Implementing the Responsibility to Protect: The 2009 General Assembly Debate: An Assessment 5-6 (Aug. 2009).

79. See Kosovo Report, supra note 18.

80. See U.N. Charter art. 2 para. 7 ("Nothing contained in the present Charter shall authorize the United Nations to intervene in matters which are essentially within the domestic jurisdiction of any state or shall require the Members to submit such matters to settlement under the present Charter; but this principle shall not prejudice the application of enforcement measures under Chapter VII.").

81. Implementing the Responsibility to Protect, supra note 73, ๆ 11. 
R2P means that before the Security Council can authorize the use of force, peaceful and coercive, non-military options must have been exhausted. In practice, the exhaustion of peaceful measures means that the international community should first resort to diplomacy, attempt to secure ceasefires, impose sanctions, or refer the situation to the International Criminal Court (ICC), before authorizing the use of force. When turning to the question of authorizing the use of force to protect populations, the Secretary-General's Report provides that military force can only be authorized through Chapter VII of the UN Charter. $^{82}$

\section{B. Libya}

The March 2011, NATO led, intervention to prevent atrocity crimes being committed by the government of Libya against its own citizens marks the first major instance of Security Council practice under R2P's third pillar. ${ }^{83}$ Following extensive human rights abuses and statements of intent to commit mass atrocities by Muammar Qaddafi, ${ }^{84}$ on February 26, 2011, the Security Council passed Resolution $1970^{85}$ in an attempt to resolve the Libya crisis peacefully. The resolution cited the "Libyan authorities' responsibility to protect its population," ${ }^{86}$ further referring the Libyan situation to the ICC and imposing an arms embargo, travel ban, and asset freeze on a number of specified individuals. ${ }^{87}$

In the weeks that followed Resolution 1970, it became clear that Qaddafi had no intention of stopping his attacks and that if the international community was to successfully protect the Libyan population, stronger measures were required. ${ }^{88}$ As a result, on March 2, 2011, the Security Council authorized all necessary measures to protect civilians and civilian-populated areas under threat of attack by Qaddafi forces. ${ }^{89}$ The authorization of the use of force resulted in a

82. Id. ๆ $49-50$.

83. Responsibility to Protect: The Lessons of Libya, The ECONOMIST, May 19, 2011, http://www.economist.com/node/18709571.

84. See The Crisis in Libya, InT'L CoAlition For the Responsibility to PROTECT, http://www.responsibilitytoprotect.org/index.php/crises/cris is-in-libya (last visited Mar. 6, 2013).

85. Press Release, Security Council, In Swift, Decisive Action Security Council Imposes Tough Measures on Libyan Regime, Adopting Resolution 1970 in Wake of Crackdown on Protestors (Feb. 26, 2011), available at http://www.un.org/News/Press/docs/2011/sc10187.doc.ht $\mathrm{m}$.

86. S.C. Res. 1970, pmbl., U.N. Doc. S/RES/1970 (Feb. 26, 2011).

87. See id.

88. The Crisis in Libya, supra note 84 .

89. S.C. Res. 1973, pmbl., U.N. Doc. S/RES/1973 (Mar. 17, 2011). 
NATO military campaign that disabled forces loyal to Qaddafi and brought an end to their attacks on civilians..$^{90}$

Resolution 1973 authorized the use of force in Libya on the basis of R2P's third pillar. The Security Council explicitly invoked Libya's failure to uphold its responsibility to protect its population as justification for Chapter VII intervention..$^{91}$ Moreover, the Security Council issued Resolution 1973 following the exhaustion of peaceful means in Resolution 1970, acting in accordance with the R2P doctrine. ${ }^{92}$

From the R2P perspective, the importance of Libya was threefold. First, Resolution 1973 reaffirmed pillars one and two of the doctrine. Resolution 1973 reiterated the responsibility of the Libyan authorities to protect its population, reaffirming that the parties to armed conflicts bear the primary responsibility of taking all feasible steps to ensure the protections of civilians. ${ }^{93}$

Second, the Security Council authorized intervention in Libya demonstrates international law's extension to allow the use of force in situations where atrocity crimes may occur, or are imminent; Resolution 1973 stated "that widespread and systematic attacks currently taking place in the Libya Arab Jamahiriya against the civilian population may amount to crimes against humanity." ${ }^{44}$

Third, intervention in Libya reaffirmed the Security Council's belief that the protection of civilians and civilian populated areas is of fundamental importance to the international community. This is because Resolution 1973 expressed the Security Council's "determination to ensure the protection of civilians and civilian populated areas." ${ }^{95}$

\section{R2P AND THE SyRIA CRISIS}

Despite its rapid development and use in Libya, the Syria crisis demonstrates that R2P is still missing a crucial component: what to do when the Security Council fails to act in the face of ongoing mass atrocity crimes. One argument is that nothing can be done; the Security Council must authorize any use of force under R2P and the stability of the international order requires so. This article argues that

90. The Crisis in Libya, supra note 84.

91. S.C. Res. 1973, supra note 89, pmbl.

92. See $i d$. (noting that Libyan authorities failed to comply with resolution 1970).

93. See id.

94. Id. This standard of proof equates to a civil test of balance of probabilities and is contrasted with higher burdens of proof such as a "prima facie case" and "beyond reasonable doubt".

95. Id. (emphasis omitted). 
there is an alternative. In the face of Security Council inaction, a regional organization or coalition of the willing should be able to authorize and undertake the limited use of force to protect populations from mass atrocity crimes. The case of Syria indicates why such an evolution of the R2P doctrine is necessary, and how it might be applied in practice.

In March 2013, after twenty-four months of conflict, the scale of the Syria crisis rivals the worst humanitarian tragedies of the past two decades. ${ }^{96}$ In August 2012, the UN Human Rights Council found that the Syria crisis was being driven by a "state policy" of deliberate attacks against civilians amounting to war crimes and crimes against humanity. ${ }^{97}$ Although Syria would appear to present a textbook case for Security Council action under its Chapter VII powers, Russia and China have vetoed three separate resolutions aimed at holding the Assad regime accountable. Although Russia claims that its opposition is grounded in concerns that R2P may be abused by powerful states, the real reason is likely strategic; Russia has close ties with the Syrian Government and an interest in maintaining the status quo. For instance, Syria hosts a significant Russian naval base at Tartus. ${ }^{98}$

\section{A. Preventing and Halting Atrocity Crimes When the Security Council Fails to Act}

Whether R2P's third pillar should allow limited use of force when the Security Council fails to act is a complicated and delicate question. The international community is generally adverse to any use of force outside the Security Council ${ }^{99}$ and it is a foundational principle of international law that the use of force should be avoided wherever possible. ${ }^{100}$ Moreover, any use of force without Security Council authorization raises concerns that powerful states could unnecessarily violate a weaker state's sovereignty and that the importance the UN Charter attaches to state sovereignty may be undermined. ${ }^{101}$

96. The crises in Bosnia, Kosovo, and Rwanda all involved mass atrocity crimes, though to be sure the death toll in Rwanda was far greater than in the Balkan conflicts or in Syria as of March 2013. In particular, several analysts have drawn parallels between Syria and Bosnia crises. See, e.g., Jackie Northam, Syrian Conflict a Haunting Reminder of Bosnia, NPR, June 23, 2012, http://www.npr.org/2012/06/23/155 622562 /syrian-conflict-a-haunting-reminder-of-bosnia.

97. Report on Syrian Arab Republic, supra note 5, ๆ $50,57$.

98. See Sharples, supra note 10.

99. See U.N. Charter, art. 2 para. 4 (prohibiting the use of force against sovereign states).

100. See id. art. 2 para. 7 , art. 51.

101. Mikulaschek, supra note 8, at 20, 24. 
At the same time, the prohibition of mass atrocity crimes is now recognized as jus cogens, ${ }^{102}$ or fundamental to the international system. Such status in international law is vitally important, because it reminds the international community that it should prevent atrocity crimes wherever possible. Moreover, as Bosnia, Rwanda, Kosovo, Darfur, and now Syria demonstrate, the Security Council will not always act to prevent mass atrocities, either in a timely and decisive manner, or at all.

When the Security Council fails to act, this article argues that R2P's third pillar should allow a regional organization or coalition of the willing to authorize and undertake the limited use of force to protect populations from atrocity crimes. To mitigate concerns regarding state sovereignty and the use of force without Security Council authorization, R2P's third pillar should only allow lowintensity military operations in limited instances. The criteria that ensure this careful balance are outlined below:

1. A prima facie case must be established: Before force can be used to prevent or halt mass atrocity crimes, a prima facie case must be established that atrocity crimes are occurring (or about to occur). This prima facie case would need to be established using evidence gathered by neutral, internationally respected sources, such as the UN Human Rights Council, the International Committee of the Red Cross, or the International Criminal Court. This is now possible due to the development of international criminal law, which has codified the elements of atrocity crimes.

2. Peaceful options must be exhausted: Consistent with R2P's second pillar, peaceful options for preventing or stopping the atrocity crimes - commencing with diplomacy and progressing to more coercive tactics such as sanctionsmust be exhausted before any low-intensity military options could be considered.

3. The Security Council must be unable to act: The Security Council must be unable to act effectively in the crisis. In practice, one or more of the Security Council's five permanent members, each of which wield a veto, must have repeatedly blocked resolutions aimed at compelling the state in question to prevent or stop mass atrocity crimes and fulfill its responsibility to protect its

102. See M. Cherif Bassiouni, Searching for Peace and Achieving Justice: The Need for Accountability, 59 LAW \& Contemp. Probs. 9, 17 (1996) (noting that crimes against humanity, genocide, war crimes, and torture are international crimes rising to the level of jus cogens, and therefore, states have an obligation to extradite or prosecute suspected criminals). 
population. Moreover, the prospects for effective Security Council action must be remote, i.e., because one or more permanent members have announced their intention to oppose any coercive measures against the state committing atrocities.

4. Any military force used must be limited to low-intensity options designed to protect populations: States would only be privileged to use low-intensity military options designed to protect populations, such as no-fly zones and humanitarian safe zones. Limiting military force in this way would help to ensure that states are acting out of the right intentions and using force that is proportional to achieving R2P's humanitarian goals.

5. The use of low-intensity military force must be authorized by a legitimate authority: Consistent with the ICISS report, this article argues that the legitimate authority for a no-fly zone or humanitarian safe haven could come from a number of sources, including a broad international coalition, a regional political or security organization, or the UN General Assembly.

6. The intervention must come at the request of credible opposition groups: Implementing a no-fly zone or humanitarian zone within a sovereign state would also require a specific request for intervention from opposition groups that represent victims of atrocity crimes.

\section{B. Pillar Three of the Responsibility to Protect When the Security Council Fails to Act}

This article discusses each criterion below, describing the safeguards that ensure consistency with international law governing the use of force. Moreover, to illustrate how these criteria would apply in future instances of mass atrocities, this article uses the Syria crisis as a practical case study.

\section{A prima facie case must be established}

Before the international community can use low-intensity military options to protect populations, a prima facie case of ongoing mass atrocity crimes must be established. ${ }^{103}$ Prima facie here is used in the

103. This view is supported by recent Security Council practice and academic opinion. When authorizing Chapter VII powers in UN Security Council Resolution 1973 (2011), war crimes had not been proven, therefore supporting the requirement of prima facie case only. For detailed academic discussion on the evidentiary standards required for R2P, see Stuart Ford, Is the Failure to Respond Appropriately to a Natural Disaster a Crime against Humanity? The Responsibility to Protect and 
strong sense of the common law concept; as described by the U.S. Supreme Court, a prima facie case constitutes evidence sufficient to create a "legally mandatory, rebuttable presumption" on the part of the opposing party. ${ }^{104}$ In the context of R2P, the prima facie case requirement would place the burden of proof on the international community, ${ }^{105}$ mitigating concerns about R2P's abuse by selfinterested states. As the ICISS report noted, legitimate humanitarian interventions must have a "just cause," which contemplates the use of force only in situations where large scale loss of life or ethnic cleansing were occurring or about to occur. Consistent with the ICISS report, a prima facie case requirement would also help to ensure that any use of force under R2P would be "to halt or avert human suffering." 106

A prima facie case of ongoing mass atrocity crimes need not be made in a formal court of law. Instead, international organizations, which are now capable of investigating mass atrocity crimes and making their findings publicly available, can provide an independent, transparent source of evidence. The UN Human Rights Council (UNHRC), an inter-governmental body of forty-seven states "responsible for the promotion and protection of all human rights around the globe," can establish commissions of inquiry to determine the existence of atrocity crimes. The International Committee for the Red Cross (ICRC) now lists protecting civilians in armed conflicts as one of its primary objectives; its delegates visit conflict areas to ensure that "authorities and other constituted groups comply with their obligations under" international humanitarian and international human rights law. ${ }^{107}$ Similarly, the ICC Office of the Prosecutor has a dedicated investigations unit tasked with gathering possible evidence of atrocity crimes. ${ }^{108}$ Recognized experts, such as leading academics and former prosecutors, can also play a key role in evaluating whether atrocity crimes are occurring within a sovereign state.

Individual Criminal Responsibility in the Aftermath of Cyclone Nagris, 38 DenV. J. InT'L L. \& POL'y 227, 240 (2010).

104. See Tex. Dep't of Cmty. Aff. v. Burdine, 450 U.S. 248, 254 n.7 (1981).

105. See supra note 103 and accompanying text.

106. See ICISS Report, supra note 11, at XII.

107. Protection of the Civilian Population, InT'L Comm. OF THE RED CRoss (Oct. 29, 2010), http://www.icrc.org/eng/what-we-do/protecting-civili ans/overview-protection-civilian-population.htm.

108. Article 53 of the Rome Statute provides that before initiating an investigation, the prosecutor must determine whether "there is a reasonable basis to proceed with an investigation" by taking into account, inter alia, whether there is "a reasonable basis to believe that a crime within the jurisdiction of the Court has been committed or is being committed." Rome Statute of the International Criminal Court, art. 53, July 17, 1998, 2187 U.N.T.S. 90. 
The international community would be able to ensure objectivity in this process because it now has clear, well-defined standards by which to determine whether a state is committing mass atrocity crimes. Amongst others, the International Criminal Tribunals for Rwanda and the Former Yugoslavia and the ICC, including the Rome Statute that created it, constitute a robust jurisprudence that has codified the elements of atrocity crimes.

In the case of Syria, a prima facie case would consist of welldocumented evidence from multiple independent sources that the Assad regime had intentionally committed mass atrocity crimes. The UNHRC has been actively involved in investigating mass atrocity crimes in Syria, and has established a Commission of Inquiry for this purpose. According to a February 2012 UNHRC Report, Assad's security forces have committed "widespread, systematic, and gross human rights violations" 109 by indiscriminately using heavy weapons, including tanks, artillery, and helicopter gunships, against civilians. ${ }^{110}$ Additionally, the Report found that Syrian forces had deliberately shot civilians, shelled residential areas, and tortured hospitalized protesters. ${ }^{111}$ That Report also found that Assad's security forces had summarily executed unarmed protesters, targeted women and children with snipers, and attacked residential areas with indiscriminate weapons such as mortars. ${ }^{112}$ Echoing the language of R2P's third pillar, the Report concluded that Syria has "manifestly failed" to protect its own people. ${ }^{113}$

The majority of these attacks, the UNHRC Report found, have been directed against unarmed civilians. In one such incident, on December 21, 2011, Syrian government forces "attacked a group of activists who had sought refuge in the village mosque. . . . After the forces withdrew, 60 bodies were discovered . . . the victims appeared to have been tortured before their execution." 114 Since the February 2012 UNHRC Report was released, new atrocities have been reported on an almost daily basis. In the Houla region, Syrian militias aligned with the government, known as shabiha, executed over one hundred civilians, leading a number of western states to expel Syrian diplomats in protest. ${ }^{115}$

109. Report on the Syrian Arab Republic, supra note 5, ฯ 2.

110. See id. ๆ \9-46 (describing the tactics used by Syrian state forces).

111. See $i d$.

112. See id.

113. Id. ब 126.

114. Id. ๆ 42.

115. Houla: How a Massacre Unfolded, BBC, June 8, 2012, http://www.bbc. co.uk/news/world-middle-east-18233934. See also Martin Chulov, Houla Massacre: UN Resolution Condemns Syria, The GuARdian (UK), June 
In response to the widespread international condemnation over Houla, ${ }^{116}$ the Syrian government claimed that it was legitimately targeting "terrorists," who were themselves responsible for the mass killings. ${ }^{117}$ Yet even when Syrian forces have attacked armed opposition forces, such as fighters from the Free Syria Army (FSA), they have done so in a way that also deliberately targets civilians in violation of international law. In December 2011, during a Syrian military operation in Bab Amr, Homs against the FSA, the February UN Report found that "[r]esidential buildings . . . were shelled by tanks and anti-aircraft guns," and "[s]tate snipers also shot at and killed unarmed men, women, and children."118 The February 2012 UNHRC Report also found that defectors from the Syrian forces have been "summarily executed."119 Evaluating these findings in their totality, the UNHRC concluded that the Syria crisis is being driven by a "state policy" of deliberate attacks against civilians amounting to war crimes and crimes against humanity. ${ }^{120}$

In Syria, international experts have also contributed to building a prima facie case. Professor David Crane, former Chief Prosecutor to the Special Court of Sierra Leone, has led a team in writing a detailed report documenting the atrocities that have occurred in Syria since March 2011. ${ }^{121}$ Professor Crane's report considers and analyzes reports from news agencies and NGOs, concluding that there is evidence to support an allegation that forty individuals within the Assad regime have committed crimes against humanity. ${ }^{122}$ Investigative reports by leading NGOs, such as a Human Rights Watch, reinforce Professor Crane's conclusions. ${ }^{123}$

1, 2012, http://www.guardian.co.uk/world/2012/jun/01/syria-houla-ma ssacre-un-resolution.

116. See, e.g., Philip Gourevich, What Has the Houla Massacre Changed?, The New YORKER, May 29, 2012, http://www.newyorker.com/onlin e/blogs/newsdesk/2012/05/what-has-the-houla-massacre-changed.html.

117. Security Council Debates Response to Houla, AlJaZeErA, May 27, 2012, http://www.aljazeera.com/news/middleeast/2012/05/2012527171046463 842.html.

118. Report on Syrian Arab Republic, supra note 5, ๆ 43.

119. Id. ๆ 40 .

120. $I d$. ๆ $50,57$.

121. See Syracuse University College of Law, Report on the Syrian Crisis: Mapping Atrocity in Syria.

122. See id. at 70 .

123. See, e.g., Human Rights Watch, They Burned My Heart (May 2012), available at http://www.hrw.org/sites/default/files/reports/syria0 512WebVersionReduced.pdf. 
As the Syria crisis illustrates, international criminal law has evolved in parallel with R2P. There is now an international consensus, supported by the jurisprudence of the Rwanda and Yugoslav tribunals and codified in the ICC's Rome Statute, regarding the elements of mass atrocity crimes. Moreover, the existence of mass atrocity crimes can now be independently evaluated and verified by neutral organizations, such as the UNHRC and the ICRC, which can be relied upon to document whether or not atrocity crimes are occurring and who might be responsible. In Syria, the UNHRC's Commission of Inquiry concluded that the Assad regime is responsible for mass atrocity crimes. This conclusion has been reinforced by reports from independent experts and NGOs. The Syria crisis demonstrates that it is now possible for the international community to present a prima facie case, based on objective criteria, transparent methodology, and independent sources of evidence, that a sovereign state is committing atrocity crimes.

\section{Peaceful options must be exhausted}

After establishing a prima facie case of ongoing atrocity crimes, the international community must exhaust peaceful means to compel the state to stop committing mass atrocities. This requirement corresponds to the "last resort" principle endorsed by ICISS and the UN High-level Panel for determining whether the use of force for humanitarian purposes is warranted and justifiable. As the ICISS report noted, "every non-military option for the prevention or peaceful resolution of the crisis [must be] explored, with reasonable grounds for believing lesser measures would not have succeeded." ${ }^{24}$

Policymakers have a number of tools that do not involve the use of military force to incentivize a recalcitrant state to change its behavior. These run the gamut of statecraft, including diplomatic overtures (peace plans, ceasefires); political sanctions (severing diplomatic relations, imposing travel restrictions on particular individuals); and targeted economic sanctions (arms embargos, restrictions on oil exports). In general, the international community should start with diplomacy before resorting to more coercive measures. Still, policymakers should have some flexibility in this regard, since the appropriate amount of pressure to apply will inevitably depend on the sanctioned state's behavior and particular facts of the crisis, as established by the prima facie case.

The Syria crisis illustrates the extent to which the international community must exhaust peaceful options before low-intensity military options could be considered. In Syria, the international community has tried multiple rounds of regional and UN-brokered peace plans, and sanctions without success. In fact, the Assad

124. ICISS REPORT, supra note 11, at XII. 
regime's attacks on civilians have intensified, with the regime increasingly relying on heavy military weapons such as cluster bombs and helicopter gunships.

A series of international peace plans have failed to stop the Assad regime from committing mass atrocity crimes. In December 2011, the Syrian government signed a peace plan sponsored by the Arab League, ${ }^{125}$ agreeing to form a national unity government, hold elections, ${ }^{126}$ and allow Arab League monitors to enter the country. In the three weeks following the monitors' arrival, however, more than 400 people died, prompting the League to suspend its mission on January 28, 2012. ${ }^{127}$ The following month, the Arab League temporarily halted cooperation with the Syrian government after the government rejected an Arab League resolution calling for a joint Arab League-UN peacekeeping mission. ${ }^{128}$ On February 16, 2012, the UN General Assembly condemned "widespread and systematic violations of human rights and fundamental freedoms by the Syrian authorities," calling upon the government to implement the Arab League's peace plans. ${ }^{129}$

In March 2012, the Arab League and the UN renewed their efforts by jointly appointing Kofi Annan as the UN-Arab League Special Envoy to Syria. Annan produced a Six Point Plan for ending the conflict, supported by all members of the Security Council. ${ }^{130}$ Assad agreed to the Annan Plan, which required Syrian forces to withdraw from populated areas and imposed a ceasefire. ${ }^{131}$ On April 14, 2012, the Security Council subsequently adopted Resolution 2042, supporting the ceasefire and authorizing thirty unarmed observers to monitor implementation of the Annan Plan. A week later, the Security Council passed Resolution 2043, which established the UN

125. Syrian Government Accepts Annan Peace Plan, BBC, Mar. 27, 2012, http://www.bbc.co.uk/news/world-middle-east-17522398.

126. Kareem Fahim, Arab League Proposes New Peace Plan for Syria, N.Y. Times, Jan. 23, 2012, at A8.

127. Colum Lynch, 400 Killed in Syria Since Arab League Monitors Arrived, U.N. Says, WASH. POST, Jan. 10, 2012, http://articles.washingtonpost. com/2012-01-10/world/35438262_1_arab-league-french-ambassadorgerard-araud-latakia; Arab League Suspends Syria Mission, BBC, Jan. 28, 2012, http://www.bbc.co.uk/news/world-middle-east-16774171.

128. Syria Rejects New Arab League Peace Mission Proposal, BBC, Feb. 13, 2012, http://www.bbc.co.uk/news/world-middle-east-17008597.

129. G.A. Res. 66/253, ๆ 2, U.N. Doc. A/Res/66/253 (Feb. 21, 2012).

130. Syria 'Agrees' to Peace Plan Deadline, Annan Tells UN, BBC, Apr. 2, 2012, http://www.bbc.co.uk/news/world-middle-east-17587438.

131. Id. 
Supervision Mission in Syria (UNSMIS), a ninety-day deployment of up to 300 additional unarmed military observers. ${ }^{132}$

Similarly, sanctions have also been ineffective in pressuring the Assad regime to stop its attacks on civilians. The United States, European Union, and Arab League imposed extensive sanctions that restrict the travel and freeze the assets of Syrian officials, ${ }^{133}$ block the purchase of Syrian oil, ${ }^{134}$ and target Syrian information technology. ${ }^{135}$ The EU has also imposed seventeen rounds of sanctions, targeting luxury items as well as goods and technologies that can be used for internal suppression. ${ }^{136}$

\section{The Security Council must be unable to act}

Before force can be used outside the Security Council, the international community must have repeatedly tried, and failed, to achieve consensus within it. Moreover, the prospects for any future Security Council action must be remote due to opposition by one of the Council's Permanent Members. By setting a high diplomatic threshold, this criterion ensures that the Security Council's primary role in authorizing the use of force is respected. It also ensures that states cannot abuse R2P to bypass the Security Council and use force for their own aims.

In Syria, for instance, the Security Council has failed to pass three strongly-worded resolutions authorizing peaceful measures to end the conflict due to open Russian and Chinese opposition. In October 2011, the first resolution threatened sanctions if the Syrian government did not immediately end violence against civilians. ${ }^{137}$ In February 2012, the second resolution did not threaten sanctions but called on Assad to leave office and supported the Arab League's peace plan. ${ }^{138}$ In July

132. S.C. Res 2042, ๆ 5, U.N. Doc. S/RES/2043 (Apr. 21, 2012).

133. Katherine Marsh, Syria Sanctions Declared as Violent Crackdown Continues, The Guardian (UK), May 6, 2011, http://www.guardian.co. uk/world/2011/may/06/syria-sanctions-crackdown-eu.

134. See Report on Syrian Arab Republic, supra note 5, ฯ 34.

135. Fact Sheet, U.S. Treasury Dep't, Off. of Public Aff., New Executive Order Targeting Human Rights Abuses via Information Technology (Apr. 23, 2012), available at http://www.treasury.gov/resource-center/ sanctions/OFAC-Enforcement/Documents/ghravity_eo_fact_sheet.pdf.

136. Stephen Castle, European Union Tightens Sanctions, N.Y. TIMES, July 24, 2012, at A8.

137. Russia and China Veto UN Resolution Against Syrian Regime, THE GUARDiAn (UK), Oct. 4, 2011, http://www.guardian.co.uk/world/2011/ oct/05/russia-china-veto-syria-resolution.

138. Paul Harris et al., Syrian Resolution Vetoed by Russia and China at United Nations, The GUARDiAn (UK), Feb. 4, 2012, http://www.guardi an.co.uk/world/2012/feb/04/assad-obama-resign-un-resolution. 
2012, Russia and China vetoed a United Kingdom-drafted resolution sponsored by the US, France, and Germany that threatened sanctions unless the Syrian government withdrew heavy weapons from populated areas within ten days. ${ }^{139}$ Even as the international community has seemingly abandoned efforts to stop the crisis through Security Council action, violence in Syria has continued to intensify.

4. Military force must be limited to low-intensity options designed to protect populations

Any use of force would be limited to low-intensity military options, such as the creation and enforcement of a no-fly zone or humanitarian safe zone. These options would satisfy both the "right intentions" and "proportionality" standards proposed by the ICISS report and the UN High-level Panel for the legitimate use of force for humanitarian purposes. ${ }^{140}$ Under the "right intentions" standard, states must be motivated by a desire to save civilian lives rather than self-interest. ${ }^{141}$ One test for "right intentions" is whether the military force is "directed against the territorial integrity or political independence" of the state. ${ }^{142}$ In addition, the military force used must be proportional to the humanitarian goal of protecting at-risk populations. ${ }^{143}$ During the 2003 Iraq war, for instance, the United States and its allies found wide support for no-fly zones to protect the

139. Russia, China Veto Syria Resolution at U.N., The Wall Street JOURNAL, July 19, 2012, available at http://www.bbc.co.uk/news/worldmiddle-east-18233934.

140. See ICISS REPORT, supra note 11, at XII. Although these criteria were initially designed to test the legitimacy of the use of force with Security Council authorization, they can also be applied to the use of force without Security Council authorization. As discussed above, first two criteria-"just cause" and "last resort"-largely track the first two pillars of R2P Syria presents a "just cause" for intervention because the international community has established a prima facie case of ongoing mass atrocity crimes. The use of force in Syria would be a "last resort" because a succession of peace plans, ceasefires, and economic sanctions have not stopped the Assad regime from attacking civilians.

141. Joyner, supra note 15 , at 712 . It is important that the intervening state/states not be perceived as acting primarily with an ulterior motive, using humanitarian interventions as a pretext for less legitimate motives such as revenge, power or land grabs, or strategic interests. See, e.g., International COMmission on Intervention AND State Sovereignty, The Responsibility to Protect: Research, BIBLIOGRAPHY, BACKGROUND 54-55 (Dec. 2001) (discussing how India's 1971 intervention in Pakistan was ill-received by the international community because India did not even claim humanitarian reasons as the primary justification for its intervention).

142. Joyner, supra note 15 , at 714 .

143. A More Secure World, supra note 1, ๆ 207(d). 
Kurds, while the eventual invasion of Iraq to overthrow Saddam Hussein was met with considerable resistance from the international community. ${ }^{144}$

In Syria, given the Assad regime's use of air power against the civilian population, a no-fly zone - an area above Syria patrolled by the air forces of coalition of states - could be a proportional military response to the crisis. ${ }^{145}$ No-fly zones were a fixture during 1990s peacekeeping operations ${ }^{146}$ and were imposed on Iraq in $1991^{147}$ and in Bosnia in 1992. ${ }^{148}$ In 2011, the Security Council authorized a no-fly zone in Libya. ${ }^{149}$ There, as in Syria, the government used fighter jets and helicopter gunships against civilian protestors. ${ }^{150}$ States have sometimes been willing to establish no-fly zones in the past without Security Council authorization. In 1991, for instance, the United States, the United Kingdom, and France established a no-fly zone in Iraq in order to protect the Kurdish civilian areas, and did so without explicit Security Council authorization. ${ }^{151}$ The no-fly zone prevented Iraqi air forces from using Iraqi airspace, ${ }^{152}$ and commentators credit it with deterring further Iraqi aggression against the Kurdish population. ${ }^{153}$

Humanitarian safe zones are another low-intensity military option consistent with right intentions and proportionality criteria. The purpose of a humanitarian zone is to shelter and protect civilian populations facing an imminent crisis or threat. ${ }^{154}$ Although humanitarian zones are often created without a state's consent, their primary objective is to safeguard civilian populations. Like no-fly zones, however, humanitarian zones are generally ineffective unless

144. See, e.g., Iraq War Legitimacy 'Questionable,' Says Ex-Diplomat, BBC, Nov. 29, 2009, http://news.bbc.co.uk/2/hi/8382194.stm.

145. Alexander Benard, Lessons From Iraq and Bosnia on the Theory and Practice of No-Fly Zones, 27 J. STRATEGIC Stud. 454, 455 (2004).

146. Id.

147. No-Fly Zones: The Legal Position, BBC, Feb. 19, 2001, http://news.bb c.co.uk $/ 2 / \mathrm{hi} /$ middle_east/1175950.stm.

148. S.C. Res 781, ๆ 1, U.N. Doc. S/RES/781, (Oct. 9, 1992).

149. S.C. Res 1973 , supra note 89 , ๆ 6.

150. Fresh Violence Rages in Libya, ALJAzEeRA, Feb. 22, 2011, http:// www.aljazeera.com/news/africa/2011/02/201122261251456133.html.

151. See No-Fly Zones: The Legal Position, supra note 147.

152. Operation Northern Watch, GLOBAL SECURITY, http://www.globalsecur ity.org/military/ops/northern_watch.htm (last visited Mar. 6, 2013).

153. Benard, supra note 145 , at 465.

154. See Hikaru Yamashita, Humanitarian Space and International Politics: The Creation of Safe Areas 4 (2004). 
there are armed forces with the authority and resources to protect them.

The experience of the United States and its allies in Iraq, where they created a humanitarian zone in 1991 against the express wishes of the Iraqi government, demonstrate how effective these zones can be in protecting civilians. Saddam Hussein's attacks on Kurdish populations in the north had led an estimated 1.5 million Kurds to flee their homes, with many heading towards Turkey and Iran. ${ }^{155}$ Kurdish leaders appealed to France, Saudi Arabia, the UK, and the US, requesting immediate action by the UN. In early April, the Security Council passed Resolution 688 encouraging states "to contribute to ... humanitarian relief efforts" and demanding that Iraq allow such efforts within the state. ${ }^{156}$

The Iraqi government strongly opposed the plan for humanitarian zones, and said it would do everything in its power to prevent their creation. Nonetheless, in mid-April, coalition forces moved into northern Iraq with the express intention of setting up camps for Kurdish refugees and coordinating humanitarian aid. ${ }^{157}$ The zone lasted about three months and safeguarded some 450,000 Kurdish refugees before they were able to return home. ${ }^{158}$

5 . The use of low-intensity military force must be authorized by a legitimate authority

When the Security Council fails to act to prevent or halt atrocity crimes, a legitimate authority must authorize any use of force. ${ }^{159}$ In accordance with earlier instances of humanitarian intervention without Security Council authorization, ${ }^{160}$ the legitimacy of an intervention will be greater where military action is undertaken by a

155. Iraq Conflict History, INT'L CRISIS GRP., http://www.crisisgroup.org /en/publication-type/key-issues/research-resources/conflict-histories /iraq.aspx (last updated Jan. 2010).

156. S.C. Res. 688, ๆ 2, 6 U.N. Doc. S/RES/688 (Apr. 5, 1991).

157. Peter Malanczuk, The Kurdish Crisis and Allied Intervention in the Aftermath of the Second Gulf War, 2 Eur. J. INT'L L. 114, 119-20 (1991).

158. Id. at 121 .

159. See, e.g., ICISS REPORT, supra note 11, at XII.

160. The military intervention in Kosovo was led by NATO. 
regional security organization, a coalition of the willing, ${ }^{161}$ or some form of multilateral operations. ${ }^{162}$

One possible basis for this authority would be a broad-based international coalition, including representatives from neighboring states. A regional political or security organization, such as the European Union, the African Union, or the Arab League, could also legitimately authorize an R2P intervention. The ICISS report endorsed regional or sub-regional organizations pursuing collective action within their boundaries, on the basis that member states to those organizations are more familiar with local political actors and are more likely to bear the costs of any humanitarian crisis on their borders. ${ }^{163}$ Like the ICISS report, the UN High Level Panel also approved of the trend towards using regional coalitions to stop atrocity crimes. ${ }^{164}$ Another possible basis of authority would be the General Assembly's "Uniting for Peace" procedure. ${ }^{165}$

6 . The intervention must come at the request of credible opposition groups

An intervention taken pursuant to specific requests from victims' representatives would also increase its perceived legitimacy and chances of success. In northern Iraq, for instance, leaders of the Kurdish community appealed to France, the UK, and the US to protect their people from Saddam Hussein; ${ }^{166}$ similarly, during the Kosovo crisis, the Kosovo Liberation Army requested help from the international community on numerous occasions. ${ }^{167}$ Both requests led

161. For example, unilateral intervention by Vietnam in Cambodia in 1975 was widely condemned because of the global distrust of communist governments at that time. See Sean D. Murphy, Humanitarian InTERVEntion: The United NAtions in an Evolving World ORder 104 (1996).

162. Mikulaschek, supra note 8 , at 24; Saban Kardas, Humanitarian Intervention: The Evolution of the Idea and Practice, PERCEPTIONS: J. INT'L AFF., Fall \& Winter 2003, at 21.

163. ICISS REPORT, supra note 11 , at 53.

164. A More Secure World, supra note 1, ब 272 ("Recent experience has demonstrated that regional organizations can be a vital part of the multilateral system. . . . The key is to organize regional action within the Charter and the purposes of the United Nations. . ..")

165. ICISS REPORT, supra note 11, at 53.

166. Malanczuk, supra note 157 , at 121 .

167. Carlotta Gall, Conflict in the Balkans: In Kosovo; Top Ethnic Albanian Rebel Asks NATO to Start Strikes, N.Y. TIMES, Mar. 23, 1999, http:// www.nytimes.com/1999/03/23/world/conflict-balkans-kosovo-top-eth nic-albanian-rebel-asks-nato-start-strikes.html?pagewanted=all\&src $=$ pm. 
to international military interventions that were widely viewed as legitimate, despite the absence of Security Council authorization.

Applying this criterion to Syria, a request for low-intensity military operations could come from a consensus among several groups representing victims of atrocity crimes, including the National Coalition for Syrian Revolutionary and Opposition Forces (Syrian National Coalition) interim Prime Minister, Mr. Ghassan Hitto, ${ }^{168}$ Local Coordinating Committees, Revolutionary Council, and the Free Syrian Army. To be sure, achieving consensus among opposition groups during a humanitarian crisis can be challenging. Syrian opposition groups initially disagreed about whether foreign military intervention was necessary or prudent, ${ }^{169}$ their views changed as the crisis intensified. ${ }^{170}$

\section{CONCLUSION}

International law relating to the use of force to prevent atrocity crimes is still evolving. Even so, the R2P doctrine reflects a growing international consensus on several issues: (1) sovereignty entails the inherent responsibility to protect populations from mass atrocity crimes, the prohibition of which is fundamental to the international system; (2) the protection of populations from mass atrocities is primarily the responsibility of the state; (3) when a state is unable to prevent atrocity crimes from occurring, the international community should encourage and help that state to meet its sovereign obligations; (4) when a state manifestly fails to protect its population, the international community should first attempt to protect populations through peaceful means; and (5) once peaceful measures have been exhausted, the international community has the right to use force to bring an end to mass atrocities.

Despite R2P's important role in shaping the international community's responses to mass atrocities, the doctrine has limitations. As the Syria crisis demonstrates, instances of mass human rights violations reminiscent of Bosnia and Rwanda still persist, largely because of Security Council inaction. As a result, the international

168. The United States, United Kingdom, France, Turkey, and Gulf States have recognized the National Coalition for Syrian Revolutionary and Opposition Forces as the legitimate representative of the Syrian people. See US Recognises Syria Opposition Coalition Says Obama, BBC, Dec. 12, 2012, http://www.bbc.co.uk/news/world-middle-east-20690148.

169. Randa Slim, Meet the Syrian Opposition, Foreign PoL'Y, Nov. 1, 2011, http://mideast.foreignpolicy.com/posts/2011/11/02/meet_syrias _opposition.

170. See, e.g., Syria Rebel Leader Wants Libyan-style Arab Initiative, REUTERS, Sept. 19, 2012, http://www.reuters.com/article/2012/09/19 /us-syria-sieda-libya-idUSBRE88I0H020120919 
community must now ask what happens when the Security Council fails to act. In answering this delicate question, this article has argued that R2P's third pillar should allow a regional organization or coalition of the willing to authorize, and use, limited military force to protect populations from mass atrocity crimes. To balance countervailing concerns, this article has proposed a framework for the use of limited military force under R2P's third pillar when the Security Council fails to act. These criteria have attempted to reconcile the jus cogens status of the prohibition of atrocity crimes, with the importance that international law attaches to both state sovereignty and the UN Charter's general prohibition on the use of force.

First, a prima facie case of atrocity crimes must exist. Second, peaceful options to compel the state to protect its populations, such as diplomatic pressure and sanctions, must be exhausted, ensuring that force is used only as a last resort. Third, the Security Council must be unable to act because of repeated vetoes and continued opposition by permanent members. Fourth, any military force used must be limited to only those low-intensity options designed to protect populations, such as no-fly zones and humanitarian safe zones. Fifth, force must be authorized by a legitimate authority, which could come from a broad international coalition, a regional political or security organization, or the UN General Assembly. Sixth, the intervention must come at the request of credible opposition groups that represent the victims of mass atrocity crimes.

Over the past decade, R2P has made significant contributions to the protection of populations from mass atrocities. The doctrine has tackled, and engendered consensus on, some of international law's most difficult and controversial questions regarding the use of force. In doing so, R2P has pushed debates forward in important ways. While these developments should be applauded, the next phase of R2P's development must critically reflect, and as the framers of R2P once did, build consensus around some of the most controversial and complex issues of present-day international law. By establishing specific criteria that allow for the limited use of force when the Security Council fails to act, R2P would enable the international community to prevent the next Rwanda or Srebrenica. 